\title{
A CONSTRUÇÃO DA COMICIDADE NA TELENOVELA ÊTA MUNDO BOM!
}

\author{
LA CONSTRUCCIÓN DE LA COMICIDAD EN LA TELENOVELA ÊTA \\ MUNDO BOM!
}

\section{THE CONSTRUCTION OF COMICITY IN THE SOAP OPERA ÊTA MUNDO BOM!}

\author{
Thiago Henrique Fernandes Coelho ${ }^{1}$ \\ Ana Elvira Wuo ${ }^{2}$
}

\begin{abstract}
RESUMO
O presente artigo tem como objetivo refletir sobre como é construído o elemento cômico produzido na telenovela, a partir do recorte para análise de conteúdo da telenovela $\hat{E} t a$ Mundo Bom! (Rede Globo, 2016) escrita por Walcyr Carrasco, para isso será feito o cruzamento entre o texto e as falas dos personagens e o referencial teórico sobre o riso com base nas teorias de Henri Bergson (2001) e Vladimir Propp (1992). A partir da análise dos personagens do núcleo caipira, observamos que o que Bergson (2001) e Propp (1992) discutem sobre os conceitos do humor estão exemplificados na telenovela Êta mundo bom!, tais como: a repetição, o travestimento, associação com animais, inocência, duplicação de personagens, muita confusão por nada, etc. Estudar a telenovela em questão é refletir sobre a aplicação da teoria do cômico, pois as teorias são exemplificadas pelos personagens e situações da telenovela pesquisada.
\end{abstract}

PALAVRAS-CHAVE: comicidade; telenovela; riso;

\section{RESUMEN}

El presente artículo tiene como objetivo reflexionar sobre cómo se construye el elemento cómico producido en la telenovela, a partir del recorte para análisis de contenido de la telenovela Êta Mundo Bom! (Rede Globo, 2016) escrita por Walcyr Carrasco, para ello se hará el cruce entre el texto y las palabras de los personajes y el referencial teórico sobre la risa sobre la base de las teorías de Henri Bergson (2001) y Vladimir Propp (1992). A partir del análisis de los personajes del núcleo caipira, observamos que lo que Bergson (2001) y Propp (1992) discuten sobre los conceptos del humor están ejemplificados en la telenovela Etta Mundo Bom!, tales como: la repetición, el travestimiento, asociación con animales, inocencia, duplicación de personajes, mucha confusión por nada, etc. Estudiar la telenovela en cuestión es reflexionar sobre la aplicación de la teoría del cómico.

PALABRAS CLAVE: comicidad; telenovela; la risa;

\footnotetext{
${ }^{1}$ Mestrando em Artes Cênicas pela Universidade Federal de Uberlândia (UFU). Projeto em andamento. Estudos em artes cênicas - poéticas e linguagens da cena - comicidade e criação orientação Ana Elvira Wuo. Graduado em teatro pela Universidade Federal de Uberlândia.

2 Professora adjunta da Universidade Federal de Uberlândia-UFU.
} 


\begin{abstract}
This article aims to reflect how the comic element produced in the soap opera is constructed, from the clipping for content analysis of the soap opera Eta Mundo Bom! (Rede Globo, 2016) written by Walcyr Carrasco, intersecting text and lines of the characters with the theoretical reference on laughter based on the theories of Henri Bergson (2001) and Vladimir Propp (1992). From the analysis of the characters of the hick nucleus, we observe that what Bergson (2001) and Propp (1992) speak in their books on the concepts of humor are exemplified in the soap opera Eta Mundo Bom! Such as: repetition, the travestiment, association with animals, innocence, duplication of characters, much confusion for nothing, etc. To study the soap opera in question, is to see the theory of the comic applied in practice.
\end{abstract}

KEYWORDS: comedy; soap opera; laughter;

\title{
Introdução
}

O humor é um tema que faz parte da vida do ser humano no seu dia a dia e tem expressiva atuação no contexto sócio histórico. Trata-se de um elemento que está presente na sociedade e tem uma função de transgredir as convenções sociais, e, com isso, faz-se presente nos mais diversos meios de comunicação, seja no jornal, no rádio, na televisão ou na internet.

Desta forma, as telenovelas também se apropriam do tema do humor em suas histórias, o que pode atrair a atenção do público, por meio de seus personagens, que utilizam jargões que "caem na boca do povo" como bordões repetitivos, por exemplo : “ Tô certo ou tô errado" falado pelo personagem Sinhozinho Malta representado pelo ator Lima Duarte em Roque Santeiro, 1985. Além da telenovela citada anteriormente, muitos personagens já fizeram parte dessa história televisiva com enorme sucesso entre o público, tais como: Norminha (Dira Paes, telenovela Caminho das Índias, 2009), Foguinho (Lázaro Ramos, Cobras e Lagartos, 2006), Tancinha (Cláudia Raia, Sassaricando, 1986), entre muitos outros (MEMORIA GLOBO, 2016).

Assim, o presente trabalho tem como objetivo refletir, por meio de uma análise de conteúdo, em como é construído o elemento cômico produzido na telenovela, a partir de recorte da telenovela Êta Mundo Bom! (2016). Dentro da reflexão proposta, 
construiu-se um breve panorama com abordagem histórica para mostrar o surgimento da telenovela no Brasil, sempre tendo como foco o humor e a comicidade.

Além desse panorama, contextualizou-se a telenovela Êta Mundo Bom!, apresentando ao leitor um resumo da trama que conta a história do caipira Candinho, o qual foi abandonado em um rio e criado por uma família de caipiras. Sua mãe, depois de 30 anos, decide procurá-lo. No encontro com a sua mãe, sua vida é transformada. A obra foi baseada na história do livro Cândido de Voltaire (2010), no filme Candinho de Mazzaropi de $1954^{3}$ e, ainda, inspirado no conto de Monteiro Lobato - O Comprador de Fazendas. Nessa novela, havia o núcleo de personagens cômicos que habitavam a fazenda, esses personagens tiveram um grande destaque, inclusive o fato de usarem a palavra de duplo sentido cegonho para se referirem ao pênis. Um texto marcado muito pelo duplo sentido, por causa da limitação do horário das 18 horas, no qual a novela foi exibida. ${ }^{4}$

A telenovela Eta Mundo Bom! foi um fenômeno de audiência, em tempos em que a audiência das telenovelas está em queda, marcando números no ibope semelhantes ao de novelas exibidas há 9 anos, atingindo 36 pontos de audiência ${ }^{5}$ e provocando surpresa inclusive na própria rede Globo, com a audiência nos patamares de novela das nove. A novela encerrou-se com média geral de 27 pontos $^{6}$ e este foi um dos motivos que levou o autor deste projeto a estudar o humor dessa telenovela.

Outro personagem representativo é o professor Pancrácio (Marco Nanine) que fazia o papel de um filósofo, mas que não conseguia ganhar a vida como tal. Para sobreviver, o professor se disfarçava de diversos personagens, tais como bailarina, miss São Paulo, Marquesa de Santos, entre outros, e pedia esmolas na rua. Assim, observa-se nessa personagem a questão do elemento cômico pelo travestimento, pois

3 Disponível em http://extra.globo.com/tv-e-lazer/novela-eta-mundo-bom/nova-novela-das-seis-etamundo-bom-tem-mundo-caipira-como-pano-de-fundo-alem-de-romance-vilania-pitadas-de-humor18485652.html Acessado em 16 de agosto de 2016.

${ }^{4}$ Disponível em http://gshow.globo.com/novelas/eta-mundo-bom/ Acessado em 16 de agosto de 2016.

${ }_{5}$ Disponível em: <http://ego.globo.com/televisao/noticia/2016/08/eta-mundo-bom-bate-recorde-de-9-anose-autor-festeja-surpreso-e-feliz.html> Acesso: 16 ago 2016. Este é o padrão

${ }_{6}^{6}$ Disponível em http://www.correio24horas.com.br/single-entretenimento/noticia/eta-mundo-bom-chegaao-fim-como-maior-audiencia-das-6-desde-2007/?cHash=62425ac9951e63feeb216b7d0408da6b Acessado em 29 de agosto de 2016. 
Pancrácio se disfarçava de personagens de ambos os sexos. Segundo o dicionário Aurélio (2001), o ato de se travestir é colocar fantasia, disfarçar-se ou dissimular-se e será um dos elementos da comédia que leva ao riso, discutidos tanto por Bergson (2001) quanto por Propp (1992).

A novela apresenta um núcleo de personagens caipiras que está concentrado na Fazenda Dom Pedro II, com diversos tipos cômicos, tais como a personagem matriarca - a gananciosa "Cunegundes" - representada pela atriz Elizabeth Savalla. Tal personagem é apelidada de Boca de Fogo, mas a mesma sempre corrige, dizendo: “Meu nome é Cu (Pausa) negundes!”. A escatologia, o duplo sentido e a sexualidade são temas presentes nesse núcleo, pois além da personagem Cunegundes, a jovem Mafalda, que é representada pela atriz Camila Queiróz, fica curiosa com o que acontece entre um homem e uma mulher após o casamento. E as mulheres da família também denominam o pênis do homem de cegonho. Outro exemplo sobre o duplo sentido é quando a personagem Eponina (Rosi Campos) casou, ao invés de na telenovela falar explicitamente que ela estava fazendo sexo, nesse momento, sempre o galo cantava e os personagens brincavam com isso; já os personagens Quincas e Dita se referiam ao sexo como "as respiração boca a boca".

A escolha dessa telenovela para análise de conteúdo, proposto nesse artigo, tem como objetivo refletir sobre como ocorre a construção da comicidade. Êta Mundo Bom! mostra um tipo de humor clássico que se produz em filmes de Mazzaropi, que serviu de inspiração para essa novela, denominado pastelão, com tortas na cara, pessoas jogadas na lama.

A realização da pesquisa justifica-se pelo interesse em averiguar porque existe uma grande repercussão de telenovelas com teor cômico no Brasil, sendo que algumas reportagens, já referenciadas no trabalho, apontam que núcleos cômicos se destacam ao longo dos tempos e ganham cada vez mais espaço nas produções, tendo inclusive, na telenovela Êta Mundo Bom!, um personagem cômico como protagonista. Assim, compreende-se que, por meio do interesse do público nessas tramas aviadas pelos personagens cômicos, a sociedade possui mecanismos de apreciação do tema que podem estar aliados a representações das situações humanas e que, através da 
comicidade, o espectador pode transgredir o seu próprio cotidiano, pois segundo Bergson (2001) a comédia reflete os acontecimentos do cotidiano, muitas vezes, como uma crítica aos fatos.

\section{Procedimentos metodológicos}

Realizou-se um levantamento bibliográfico e leituras que contemplaram o tema da comédia no Brasil e na televisão com intuito de fundamentar teoricamente a reflexão. Ao longo da pesquisa apreciaram-se vídeos relacionados ao tema comédia, focando nos vídeos da telenovela em questão disponíveis na internet a fim de analisar o humor. Na época em que a telenovela foi exibida, o pesquisador assistiu à boa parte dos capítulos exibidos na televisão aberta e, desde esse momento, o tema da comicidade presente na telenovela interessou o pesquisador.

As teorias sobre o riso e humor foram amparadas por Bergson (2001) e Propp (1992), com intuito de analisar o conteúdo do humor presente na atuação e na fala dos personagens, também para compreender de que forma o autor da novela construiu as premissas cômicas. Junto a esse entendimento, considerou-se que foi importante traçar um breve histórico do surgimento da telenovela, esse percurso sucinto, contemplou novelas de cavalarias, romances, folhetins, romance-folhetim, melodrama, fotonovela, radionovela, cinema de episódios, com a finalidade de esclarecer como foi o desenvolvimento desse gênero até chegar às telenovelas atuais.

\section{Breve histórico da telenovela}

As raízes das telenovelas estão na Idade Média (séc. XI), quando obras eram lidas e interpretadas, com isso vão surgindo os saraus, que passam a ser acompanhados por músicas e também são lidas as novelas de cavalaria. Com o passar dos séculos, as ideias renascentistas também influenciam as novelas, com um grande destaque para a obra Decameron ou Decamerão de Boccaccio (1313-1375), cujo enredo 
é centrado em dez pessoas que se refugiam em uma casa de campo fugindo da Peste Negra (REBOUÇAS, 2009).

As novelas que vemos hoje na televisão sofreram influências do romance, romance-folhetim, melodrama teatral, cinema, rádio, etc. "Destaca-se a influência desde o romance-folhetim, desenvolvido na França, das soaps operas norte-americanas até as radionovelas latino-americanas” (SILVA, 2012, p. 152).

O romance surge com novelas de cavalaria, que contam as epopeias medievais. Está presente a estrutura cumulativa, a continuidade em vários episódios das aventuras dos personagens. "Esses elementos encontram-se presentes não somente no romance picaresco, heroico e pastoral da Renascença e do Barroco, mas também no romance de aventuras do século XIX" (SILVA, 2012, p. 152).

O folhetim surge no século XIX, trazendo obras literárias em prosa com uma edição seriada, sendo publicada em jornais, revistas ou periódicos (REBOUÇAS, 2009). "O folhetim nada mais é do que o teatro móvel que vai buscar o espectador em vez de esperá-lo" (ORTIZ,1991, p.56 apud REBOUÇAS, 2009, p. 3).

Contudo, romance em folhetim é diferente de romance-folhetim. O primeiro é um romance pronto, como a obra de José de Alencar, O Guarani, que foi publicado em fatias de jornais; e o segundo é construído dia a dia, em função da expectativa do público, finalizado apenas quando acabar a curiosidade do leitor. Fica clara então a filiação da novela ao romance-folhetim (FIGUEIREDO, 2003, p.70 apud REBOUÇAS, 2009, p. 3).

O melodrama surge na Idade Moderna na Inglaterra e na França, no fim do século XVIII. Sempre fez muito sucesso com as classes populares, pelo seu forte conteúdo emocional, abordando temas político-sociais da época, entre os quais: traições, conspirações, injustiças e histórias de amor.

Nessas narrativas, estão presentes personagens do povo, aristocratas e burgueses, sendo evidenciada a oposição bem e mal (mocinho e vilão) (SILVA, 2012).

As fotonovelas unem fotografia com texto com o objetivo de narrar uma história. Suas publicações podem ser em jornais, revistas ou livretos. Neste caso, o narrador ganha um papel importante na condução da história, mostrando as características de cada personagem e o desenvolvimento da narrativa (REBOUÇAS, 2009). 
As radionovelas surgem nos EUA no início do séc. XX, na década de 20, e em 1930 se espalha pela América Latina. As "óperas de sabão" como eram chamadas as radionovelas no princípio surgem nos rádios com a meta de anunciar produtos. Como os EUA passavam por período de recessão, perceberam no rádio uma oportunidade de potencializar as vendas. As radionovelas são contadas em episódios com inúmeros personagens, sem preocupação com o desfecho. Com isso, surgem casos duradouros como a The Guiding Light, que ficou no ar de 1937 até 1982 (SILVA, 2012).

O cinema de episódios também foi uma das influências das telenovelas, começou nos EUA e na Europa nas primeiras décadas do século XX. Eram filmes de curta duração, com um número fixo de episódios, quinze em geral. O fato de serem em episódios despertava o desejo do público de ir ao cinema ver a continuação da história (SILVA, 2012). Como acontece com as telenovelas, com seus diversos capítulos, cada capítulo termina com um acontecimento importante que será retomado no próximo dia, chamado de gancho pelos autores e diretores de tv.

A televisão é inaugurada no Brasil na década de 1950. As primeiras novelas traziam como referência os modelos das radionovelas. A TV Tupi lançou em 1951 a novela Sua Vida Me Pertence, com dois capítulos semanais. A 2-5499 Ocupado (1963, Tupi) é tida como a "primeira novela brasileira" devido ao fato de ser exibida diariamente. No início, as novelas brasileiras tinham como referência as produções mexicanas, argentinas e cubanas, com um elevado grau melodramático e adaptações de obras literárias como Os Miseráveis (Victor Hugo). O Direito de Nascer (1965, Tupi) foi o grande sucesso até então, mostrando a ascensão de um gênero e incentivando mais produções. (REBOUÇAS, 2009).

Beto Rockfeller, novela de Bráulio Pedroso da virada da década de 60/70, quebra com o modelo capa e espada importado da América Espanhola, trazendo um enredo moderno e atual, próximo do cotidiano. Aparece então Janete Clair na TV Globo, que absorve as propostas da telenovela Beto Rockfeller, trazendo Véu de Noiva (novela adaptada do rádio), ambientada no Rio de Janeiro com um diálogo coloquial. O tema humor aparece muito marcado em O Bem-Amado (Dias Gomes, 1973), com personagens tipo, é uma sátira do mundo político, com o personagem Odorico 
Paraguaçu e sua promessa de campanha de construir um cemitério na cidade de Sucupira. É a primeira novela colorida na televisão brasileira (REBOUÇAS, 2009).

Existem dois tipos básicos de telenovelas, o tradicional - em que o melodrama ainda é muito forte, com o elemento trágico, como exemplos temos as novelas mexicanas - Os Ricos Também Choram ou Berço de Lobos; como também as venezuelanas Cristal e Lucecita. A trama é movida por conflitos de parentescos, estratos sociais, extremamente maniqueístas. Já o estilo moderno - mais realista e próximo do cotidiano, com muitos elementos culturais, o caso das telenovelas brasileiras, como por exemplo, Escrava Isaura ou Roque Santeiro. No caso brasileiro, os esquemas são mesclados com temáticas de classes, territórios, gênero e geração. Os personagens se aproximam da vida cotidiana (SILVA, 2012). Percebemos isso na telenovela Êta Mundo Bom!, na qual aparece a regionalidade da cultura caipira.

\section{A inspiração para a telenovela $\hat{E} t a$ Mundo Bom!}

Walcyr Carrasco, o autor da telenovela, inspirou-se na história do livro de Voltaire - Cândido ou o Otimismo (2010), no filme de Mazzaropi - Candinho (1953) ${ }^{7} \mathrm{e}$ no conto de Monteiro Lobato - O comprador de Fazendas (1947, Urupês).

\section{O autor Walcyr Carrasco}

Contextualizando alguns dados sobre Walcyr Carrasco, que é um autor de telenovelas com passagens pelos canais de TV aberta - SBT, Manchete e atualmente está na TV Globo. Suas telenovelas têm muita presença de personagens cômicos, que vão ganhando destaque ao longo da trama. Em 2001, escreveu $O$ cravo e a rosa, telenovela baseada na peça A megera domada de William Shakespeare, Catarina (Adriana Esteves) e Petruchio (Eduardo Moscovis) tinham uma relação "cão e gato"8, muito cômica. Nessa novela já havia o núcleo caipira da fazenda do Petruchio. Em Chocolate com Pimenta (2003), trama baseada na história do patinho feio, a família da

${ }^{7}$ Disponível em https://www.youtube.com/watch?v=Zz9jMUde2GM Acessado em 02 de março de 2017.

8 Ou seja, uma relação com muita briga. 
personagem protagonista Ana Francisca (Mariana Ximenes) é caipira. Em Alma Gêmea (2005), telenovela com enredo sobre reencarnação, o núcleo caipira teve um grande destaque com a personagem Mirna (Fernanda Souza), que vivia tentando arrumar um namorado e conversava com sua pata de estimação Doralice. Crispim (Emílio Orciollo Netto) jogava os pretendentes na lama do chiqueiro. Em 2011, Walcyr escreveu a telenovela Morde e Assopra, em que um personagem caipira xucro, o Abner, é o protagonista. Vários personagens da trama têm o linguajar caipira. Mesmo em novelas que não traziam personagens caipiras, Walcyr trazia muitos personagens cômicos (MEIRELLES, FELICIO E ARRUDA, 2010).

\section{A telenovela $\hat{E}$ ta Mundo Bom!}

A história da telenovela é bem semelhante a do filme Candinho (1954) e ao que acontece no conto O Comprador de Fazendas, no último, só altera o nome dos personagens. Walcyr Carrasco desenvolve os núcleos da cidade, trazendo a mãe de Candinho, Anastácia, que após a morte do marido, decide procurar o filho. No entanto, os sobrinhos de Anastácia, Sandra e Celso, querem a sua fortuna e vão tentar impedir que ela o encontre. Após mãe e filho se encontrarem, Sandra decidirá se casar com Candinho, para isso se aliará ao vilão Ernesto. Celso se apaixonará por Maria, que foi expulsa grávida de casa pelo pai e acolhida por Anastácia que se enxergava nela, e passará para o lado do bem. Sandra e Ernesto são os dois grandes vilões da novela e irão infernizar a vida de Candinho.

A novela citada conta com diversos núcleos, como o da família de Maria, cujo pai Severo trai a mulher com Diana, e a mãe de Maria acaba morrendo de desgosto. Braz, irmão de Maria, decide se vingar do pai, alia-se à Diana e tomam tudo dele. Também temos o núcleo da madrasta má, Ilde que maltrata o enteado cadeirante Claudinho, filho do advogado de Anastácia. O núcleo da pensão da Camélia. O Dancing da Paulina, onde Filó, Diana e outras meninas dançam. E outros núcleos menores. Contudo, esses não serão pormenorizados na pesquisa, devido ao fato do recorte ser o núcleo cômico da fazenda. 


\section{Os personagens da telenovela $\hat{E} t a$ Mundo bom!}

$\mathrm{Na}$ sequência, iniciaremos uma discussão com base nas teorias de Bergson (2001) e Propp (1992), que abordam quais são os fatores que geram comicidade como uma forma de analisar os personagens do núcleo cômico da telenovela (seja individual ou agrupado por um tema), apontando como é a construção da comicidade em cada um e como é estabelecido o jogo cômico entre eles. Os personagens são: Candinho, Mafalda, Eponina, Pancrácio, Cunegundes, Quinzinho, Quincas, Manuela, Dita e Zé dos Porcos.

\section{Candinho (ator Sérgio Guinzé)}

É um personagem muito simples, inocente e extremamente ingênuo. Traz muito carisma na relação com os outros personagens, por isso, a frase que "tudo acontece na vida é para melhorar", ganha muita força na atuação com ele, tornando-se seu bordão. Bergson (2001) aponta que a ingenuidade é um dos motores da comicidade, dá um exemplo no seu livro, de uma mulher que chega a uma cidade e, ao ficar sabendo que um vulcão foi extinto, lamenta por terem deixado este ser apagado.

O personagem Candinho da telenovela Êta Mundo Bom! tem um burro chamado Policarpo que é seu grande amigo. O personagem Candinho pede conselhos para esse burro que responde com relinchos. Candinho entende a língua do animal. Nesse parágrafo e no anterior, recorremos a Bergson para compreender o efeito cômico, quando esse está relacionado à representação do humano num animal. Bergson (2001, p. 2) explica que rimos de um animal pelo comportamento que este faz e nos remete ao ser humano. O fato de um homem conversar com um burro e este entender e responder leva o público a enxergar traços humanos no mesmo, como s e o entendimento da língua do animal fizesse parte da formação de uma linguagem entre humano e animal, nesse caso do personagem Candinho e seu parceiro Policarpo.

O sexo - Mafalda (Camila Queiróz), Eponina (Rosi Campos), Quincas (Miguel Rômulo) e Dita (Jeniffer Nascimento) 
Mafalda e Eponina são quase o espelho uma de outra, ou seja muito semelhantes. Eponina é uma Mafalda só que mais velha. Propp (1992) explica a repetição/duplicação de personagens dando o exemplo de Bóbtchinski e Dóbtchinski de Gógol, e ainda acrescenta que "pequenas diferenças contribuem para reforçar as semelhanças" (PROPP, 1992, p. 56). O que move as duas é a questão da curiosidade sobre o que acontece entre um homem e uma mulher após o casamento; porque, apesar da idade avançada de Eponina, ela ainda não casou e Mafalda é uma mocinha. Mafalda faz muitas perguntas sobre o homem, e as mulheres passam a explicar para ela que um homem tem um cegonho (pênis) e que ele bica e voa na noite de núpcias. Mais uma vez, como aponta Bergson (2001), a comparação de um animal com um homem gera comicidade, pois um é visto na forma do outro, ou seja, a mistura de características dos animais com os seres humanos.

A personagem Mafalda começa a querer ver o cegonho e a perguntar aos homens da fazenda, seu Romeu e Zé dos Porcos, o que é esse tal de cegonho; no princípio da conversa, eles não entendem, mas depois ficam com vergonha. Temos também outra característica apontada por Bergson (2001) que é a ingenuidade, esta também leva a comicidade. Observamos isso na personagem Mafalda pelo fato de ela pensar que o homem tem um pássaro no meio das pernas que bica e voa, associação que as personagens mais velhas fazem para explicar sobre o órgão sexual do homem para as moças.

Outro ponto de comicidade, que ocorre na telenovela em questão, é que Eponina, enfim, consegue desencalhar, casando-se com o doutor Pandolfo. Com a classificação indicativa no horário das 18 horas, que deve ser a faixa "livre", ou seja, pessoas de qualquer idade podem assistir à programação que tem esse faixa sinalizada, desse modo, o autor usa de vários artifícios como o "cegonho" e, quando Eponina e Pandolfo estão fazendo sexo, sempre um galo canta, criando com isso uma associação entre o ato sexual com o grito estridente de um animal. É a associação de que fala Bergson (2001) "do animal ser confundido com o humano", no caso acima o autor da novela evoca o canto do galo para simbolizar o ato sexual. Propp (1992) também discute os elementos da comicidade em comparação às ações do ser humano 
associadas a animais. Assim, o princípio cômico em sua essência é rir de algo que parece humano, mas não é, ocorrendo, assim, uma associação e um desvio ao mesmo tempo.

Os personagens Quincas e Dita se casam. Ela, sendo a empregada negra da família, a princípio, os pais do Quincas são contra o casamento, mas acabam aceitando, pois Dita enfrenta a mãe de Quincas, a personagem Cunegundes. Nessa situação, temos a comicidade do contraste apontada por Propp (1992), na qual uma empregada enfrenta a patroa e acaba casando-se com o filho de sua opositora, tudo sempre por um viés cômico. Propp (1992) dá como exemplo um cão fugindo de um gatinho. Esse tipo de situação contrastante também gera comicidade, pois pode pregar peças, ou seja, virar o jogo contra as personagens mandonas, no caso Dita acaba empurrando Cunegundes na lama do chiqueiro.

Os personagens Quincas e Dita se referem ao sexo como as respiração boca a boca. Temos aqui um dos artifícios da comédia apontado por Bergson (2001), como cômico de repetição, que é a repetição periódica de uma palavra ou cena. No caso, ao longo da novela, foi a palavra cegonho, o canto do galo e as respiração boca-boca, que a cada vez que os personagens pronunciavam, tornavam-se mais cômicas, pois já havia virado um código.

O personagem Quincas situa-se no princípio cômico apontado por Propp (1992) com falta de inteligência que provoca confusão, um certo teor na personalidade do personagem de ingenuidade ou parvoíce. Cunegundes, sabendo da burrice do filho, manda-o armar a cama em que Pandolfo e Eponina irão dormir na lua de mel, porém, na noite de núpcias, a cama acaba caindo. A motivação do Quincas é a melhor possível, mas sempre acaba dando errado. Nesse sentido, recorremos ao pensamento de Bergson (2001) que enfoca que o tolo sempre tem as melhores intenções possíveis e não mede as consequências das suas ações.

\section{Cunegundes (interpretada pela atriz Elizabeth Savalla)}

Ao ler o livro Candinho ou o otimismo, o autor Walcyr Carrasco viu esse nome peculiar e percebeu que dava para ser criado um jogo entre esse nome e a palavra "cu". Quando os outros personagens a chamavam de "boca de fogo", por conta de sua 
braveza, Cunegundes sempre corrigia seu nome, dizendo: "Meu nome é Cu-negundes!", fazendo uma pausa depois de "cu". E terminava soprando uma mecha de cabelo que ficava sobre o rosto. Algumas características dessa personagem podem ser encontradas nas definições de Bergson (2001) tais como: a questão da repetição do nome e do gesto de soprar o cabelo, a tentativa de disfarçar o ridículo do seu nome, a associação de um nome a uma parte do corpo humano. Propp (1992) ressalta o fato de que nomes de personagens podem gerar comicidade, como exemplo, o autor mostra que Shakespeare e Gógol utilizavam os mesmos recursos cômicos no enredo das peças.

Cunegundes era uma vilã, mas suas vilanias eram quebradas por recursos cômicos associados às características da personagem, seja na questão do nome, na forma de vestir e nos gestos, assim como nos aponta Bergson (2001, p.38): "É cômico todo incidente que chame nossa atenção para o físico de uma pessoa quando o que está em questão é a moral".

Outro recurso cômico que poderíamos aliar a essa dupla de personagens seria o jogo clownesco de branco e augusto (REIS, 2013) entre a personagem Cunegundes e seu marido Quinzinho, a mulher (branco) sendo o mandão e o marido (augusto) o atrapalhado e bobão. Por exemplo, em alguns momentos da cena, Quinzinho cochilava e ela o acordava, ou ela o mandava dar uma resposta e este concordava com ela, ou mesmo, quando o próprio Quinzinho chama Cunegundes de "boca de fogo", apelido que ela não tolerava. A comicidade era gerada pela indignação de ver o próprio marido ter a ousadia de falar o "tal" apelido.

Em outro momento, o grande objetivo de Cunegundes é vender a fazenda improdutiva, para isso, maquiam a mesma, roubam animais de fazendas vizinhas e levam para lá, compram produtos na cidade, pintam e reformam a casa. A família leva o banqueiro, o veterinário Josias e os dono da mercearia no bico, dizendo que quando venderem a fazenda, irão acertar a dívida. Tentam vender para vários compradores, mas não conseguem, até que aparece o trapaceiro seu Romeu, o falso comprador de fazendas. Propp (1992) expõe sobre fazer muito barulho por nada, ou seja, uma grande confusão e sempre voltar ao mesmo ponto, explicitando que isso também é um efeito cômico pertinente à comédia, porque por mais que tentassem, a família de Cunegundes nunca conseguia vender a fazenda. 
Outro elemento pertencente ao cômico é o trapaceiro trapaceado, é um tipo apontado por Propp (1992) e também aparece na telenovela, pois seu Romeu engana a família de Cunegundes se passando pelo falso comprador de fazendas, mas acaba se apaixonando por Mafalda e, quando vai embora, ganha na loteria e decide voltar para comprar a fazenda de verdade. Porém, Cunegundes começa a pedir presentes extravagantes, para aceitar seu casamento com Mafalda, tais como casaco de pele, joias, etc. E por fim, tomar banho com o dinheiro do seu Romeu, mas em meio ao banho, acontece um vendaval e leva todo o dinheiro embora, acabando assim com a chance de se vender a fazenda.

\section{Professor Pancrácio (interpretado pelo ator Marco Nanini)}

Nesse personagem é evidenciada uma crítica social sobre a questão da desvalorização da área da filosofia, pois o professor não conseguia emprego na sua profissão, tendo que usar disfarces para pedir esmolas na porta da igreja e bares. Ao longo da novela, o personagem atuou com inúmeros disfarces, tais como: cego, vedete, freira, etc. E a cada disfarce, o personagem apresentava as características dessa personagem do disfarce. Era uma metalinguagem, como Shakespeare fazia, ou seja, o teatro dentro do teatro, um ator que interpreta um personagem, que interpreta outros (ALVIM, 2010).

Recorrendo ao pensamento de Bergson (2001) quando enfatiza que a fantasia ou o disfarce é algo que nos surpreende, que foge da naturalidade, isso revela o lado cômico. É algo que é perceptível que não é real, como eram os disfarces do professor Pancrácio.

$\mathrm{O}$ ator Marco Nanini atuou com dois personagens gêmeos na telenovela, o professor de filosofia Pancrácio e o engenheiro doutor Pandolfo. Enquanto o primeiro é de personalidade alegre e bonachão, o segundo é sisudo e carrancudo. Nas características pessoais desses dois personagens, está presente a ridicularização das profissões apontada por Propp(1992) em seu livro "Comicidade e Riso", pois enquanto na telenovela pesquisada, o Pancrácio tem as características e o jeito dos filósofos, muito argumentativo e questionador, o outro personagem, Pandolfo tem a dureza da engenharia, da ciência dura, mas que acaba sendo enganado, pensando que tem um 
poço de petróleo na fazenda de Cunegundes, e o poço jorra lama, temos aqui a comédia de contraste apontada por Propp (1992), no caso do poço não jorrar o esperado.

\section{Zé dos Porcos (interpretado por Anderson di Rizzi)}

Zé dos Porcos é um personagem que se aproxima muito do personagem Jeca do Monteiro Lobato e dos personagens de Mazzaropi, contudo, tem um bom coração, e isso desperta a paixão na Mafalda. Ele cuida dos porcos na fazenda, e assim como Candinho, este conversa com os porcos. Novamente recorremos às reflexões de Bergson, pois, nesse caso, o que gera comicidade é a semelhança dos animais com o homem.

Outra questão apontada por Bergson(2001) é o mau jeito, da mecanicidade do ser, que traz a falta de controle sobre situações imprevistas. Tanto Zé dos Porcos como Candinho são atrapalhados e isso gera acidentes, que levam ao riso. Ao longo da novela, pessoas foram jogadas na lama do chiqueiro; ou, por acidente, caíram dentro do mesmo, por exemplo, quando Romeu e Zé dos Porcos brigaram por Mafalda, esta foi separar a briga e acabou caindo na lama; em outro momento, Dita enfrentou Cunegundes e a empurrou dentro do chiqueiro. Assim a citação a seguir aponta o fenômeno do desajuste perante a sociedade por um personagem denominado João Bobo:

Um outro fenômeno é constituído por João-bobo, protagonista de contos de magia. Ele é bobo apenas no começo: senta-se na estufa, "na fuligem e nas cinzas", e todos riem dele. Justamente o bobo, entretanto, revela-se mais esperto que seus irmãos e realiza diferentes empresas heroico-mágicas. Nisto reside uma filosofia toda especial. No herói dos contos de magia existe o que mais importa: a beleza espiritual e a força moral (PROPP, 1992, p. 114).

A beleza espiritual e a força moral aparecem em Zé dos Porcos e também em Candinho, pois mesmo sendo eles atrapalhados, bobos e inocentes, possuem um bom "coração", ou seja, são personagens com valores morais. Eles se preocupam com o próximo e tentam ajudar as pessoas: "Os tolos, no final das contas, suscitam a simpatia e a compreensão dos ouvintes, o bobo dos contos russos, onde os mesmos têm qualidades morais e isto é mais importante que aquilo que se chama inteligência" 
(PROPP, 1992, p. 114). Sendo assim, os personagens tolos possuem um bom coração, que conquista as pessoas, pela sua pureza.

\section{Manuela (Dhu Moraes) e Dita (Jeniffer Nascimento)}

São duas criadas da fazenda Dom Pedro II, são negras e não trazem a submissão tradicional dos empregados vistos nas telenovelas. Tanto Manuela como Dita são conscientes dos seus direitos, e por isso enfrentam os patrões e falam o que pensam. Por exemplo, Cunegundes é contra o casamento do filho Quincas com Dita, mas esta enfrenta a Boca de Fogo e casa com Quincas.

A própria Manuela não recebe pelo seu trabalho, pois a família está falida, no entanto, tem consciência disso e diz para os patrões que não é escrava. Assim, vemos a questão do contraste apontado por Propp (1992), pois é a questão do empregado enfrentando o patrão, ou seja, temos uma inversão de posições.

Nisso, entra a questão do personagem Zé dos Porcos, o faz tudo na fazenda, em diálogo com as ações das empregadas, este chega a fazer greve, então a família percebe a importância do seu trabalho, pois ficam sem leite para beber. Dessa forma, a relação dos patrões e empregados é invertida na telenovela, pois, ao mesmo tempo que recebem ordens, os empregados também enfrentam os patrões e dizem o que pensam para eles.

\section{Considerações finais}

A partir da análise do personagens do núcleo caipira da telenovela em estudo, observamos que aquilo que Bergson (2001) e Propp (1992) falam em seus livros sobre os conceitos do humor estão exemplificados na telenovela Êta mundo bom!, tais como: a repetição, o travestimento, associação com animais, inocência, duplicação de personagens, muita confusão por nada, etc. Estudar a telenovela em questão é ver a teoria do cômico aplicada, exemplificada pelos personagens e situações apresentadas.

A partir do estudo de conteúdo em que ocorre a construção da comicidade em Êta Mundo Bom!, percebe-se que isso se dá na soma do modo como o ator elabora a 
personagem, como é estabelecido o jogo de relação entre os personagens e a inserção do texto com as palavras de duplo sentido, por exemplo, a palavra cegonho.

A construção do elemento cômico e da comicidade na telenovela analisada acontece muito pela questão do duplo sentido das palavras em relação ao ato sexual, por exemplo: usar o termo cegonha no masculino - cegonho, para se referir ao pênis; o canto do galo para insinuar o ato sexual; usar a expressão "o cegonho voa e bica". Essas ocorrências, além de implicar alusão ao ato sexual, geram comicidade, pois aproximam a noção das figuras animalescas ao comportamento humano, ou também podem produzir o efeito de semelhança das partes do corpo do ser humano.

A investigação da construção da comicidade na telenovela Êta Mundo bom! exemplifica como um autor se inspira em histórias já escritas e, a partir disso, escreve sua própria telenovela, transportando um conto francês para o universo caipira paulista da década de 40-50 do século XX, evidenciando a ingenuidade, a pureza, a esperteza, a curiosidade, a inteligência, a alegria do povo caipira e, por conseguinte, do ser humano. Uma história de esperança contada de forma cômica, essa é a história de Candinho.

\section{REFERÊNCIAS}

ALVIM, A. F. D. et al. Os primeiros dramas elisabetanos: um estudo sobre William Shakespeare. In: VII SEMINÁRIO DE INICIAÇÃO CIENTÍFICA SÓLETRAS - Estudos Linguísticos e Literários. 2010. Anais... UENP - Universidade Estadual do Norte do Paraná - Centro de Letras, Comunicação e Artes. Jacarezinho, 2010. ISSN - 18089216. p. $101-113$.

BERGSON, H. O Riso: Ensaio sobre a significação da comicidade. Tradução Ivone Castilho Benedetti. São Paulo: Martins Fontes, 2001.

BERNARDO, A; Lopes, C. A seguir, cenas do próximo capítulo: as histórias que ninguém contou dos 10 maiores autores de telenovela do Brasil. São Paulo: Panda Books, 2009. 
FERREIRA, A. B. de H. Miniaurélio século XXI escolar: o minidicionário da língua portuguesa. Rio de Janeiro: Nova Fronteira, 2001.

LOBATO, M. Urupês. São Paulo: Brasiliense, 1947.

MEIRELLES, C. F; FELICIO, J; ARRUDA, L. TV Globo : novelas e minisséries / Memória Globo ; Rio de Janeiro: Zahar, 2010.

PROPP, V. Comicidade e riso. Tradução Aurora Fornoni Bernardini e Homero Freitas de Andrade. São Paulo: Ed. Ática, 1992.

REBOUÇAS, R. de A. Telenovela, história, curiosidades e sua função social. VII Encontro Nacional de História da Mídia. Fortaleza, 2009. Disponível em http://www.ufrgs.br/alcar/encontros-nacionais-1/encontros-nacionais/7o-encontro-20091/Telenovela-\%20historia-\%20curiosidades\%20e\%20sua\%20funcao\%20social.pdf Acessado em 02 de março de 2017.

REIS, D.M. Caçadores de Risos: o maravilhoso mundo da palhaçaria. Salvador, EDUFBA, 2013.

Silva, R. M. Percursos históricos da produção do gênero telenovela no Brasil: continuidade, rupturas e inovações. Conexão - Comunicação e Cultura, UCS, Caxias do Sul, v. 11, n. 21, jan./jun. 2012.

VALVANO, T. Mazzaropi e a indústria de cinema do Brasil: a importância da comédia caipira na cinematografia brasileira nos anos de 1950-1980. Novos Cadernos NAEA - v. 18, n. 3, p. 293-307, set-dez. 2015, ISSN 1516-6481 / 2179-7536. Disponível em http://www.periodicos.ufpa.br/index.php/ncn/article/view/2064 Acessado em 12 de maio de 2017.

VOLTAIRE, F-M. A. Cândido, ou, O otimismo. Tradução Jorge Silva. $1^{\text {a }}$ Ed. São Paulo: Folha de S. Paulo, 2010.

Recebido em agosto de 2018. Aprovado em outubro de 2018. Publicado em dezembro de 2018. 